\title{
THE EFFECT OF MICROTEACHING AND GUIDED FIELD PRACTICE (PLT) ON READINESS TO BECOME PROFESSIONAL TEACHER OF THE ACCOUNTING EDUCATION STUDENT STATE UNIVERSITY OF YOGYAKARTA CLASS OF 2015
}

\author{
PENGARUH KUALITAS MICROTEACHING DAN PRAKTIK LAPANGAN \\ TERBIMBING (PLT) TERHADAP KESIAPAN MENJADI GURU PROFESIONAL \\ MAHASISWA PENDIDIKAN AKUNTANSI UNIVERSITAS NEGERI YOGYAKARTA \\ ANGKATAN 2015
}

By:

Nabila Sofiarani

Accounting Education Study Program State University of Yogyakarta nabilasofiarani97@gmail.com

Arief Zuliyanto Susilo

Lecturer in Accounting Study Program State University of Yogyakarta ariefzuliyanto@uny.ac.id

\begin{abstract}
This research aims to determine whether there is an effect of the Microteaching Quality and Guided Field Practice (PLT) on Readiness to Become Professional Teacher. This research uses a quantitative approach with the respondents from the Accounting Education Student 2015 State University of Yogyakarta amounted to 63 students. Data collection techniques using a questionnaire. The data analysis technique uses multiple regression analysis. The results showed: 1) There was no significant effect of Microteaching Quality on Readiness to Become Professional Teacher with $t_{\text {count }}=-0.317$ and significance value of 0.752 . 2) There was a positive and significant effect of Guided Field Practice (PLT) on Readiness to Become Professional Teacher with $t_{\text {count }}=3.963$ and significance value of 0,000 . The determination coefficient $\left(R^{2}\right)$ is 0.208 or $20.8 \%$. These results identify that Readiness to Become Professional Teacher can be explained by the variable of Microteaching Quality and Guided Field Practice on $20.8 \%$.
\end{abstract}

Keywords: Microteaching, Guided Field Practice, Readiness to Become Professional Teacher

\section{Abstrak}

Penelitian ini bertujuan untuk menguji ada tidaknya pengaruh Kualitas Microteaching dan Praktik Lapangan Terbimbing (PLT) terhadap Kesiapan menjadi Guru Profesional Mahasiswa Pendidikan Akuntansi Angkatan 2015 Universitas Negeri Yogyakarta. Penelitian ini menggunakan pendekatan kuantitatif dengan responden berasal dari Mahasiswa Pendidikan Akuntansi Angkatan 2015 Universitas Negeri Yogyakarta berjumlah 63 mahasiswa. Teknik pengumpulan data menggunakan kuesioner. Teknik analisis data menggunakan analisis regresi berganda. Hasil penelitian menunjukkan: 1) Tidak terdapat pengaruh yang signifikan Kualitas Microteaching terhadap Kesiapan menjadi Guru Profesional dengan nilai $t_{\text {hitung }}=-0,317$ dan nilai signifikansi 0,752. 2) Terdapat pengaruh positif dan signifikan Praktik Lapangan Terbimbing (PLT) terhadap Kesiapan menjadi Guru 
Profesional dengan nilai $t_{\text {hitung }}=3,963$ dan nilai signifikansi 0,000. Besarnya koefisien determinasi $\left(R^{2}\right)$ sebesar 0,208 atau 20,8\%. Hasil ini mengidentifikasikan bahwa kesiapan menjadi guru profesional dapat dijelaskan oleh Variable Kualitas Microteaching dan Praktik Lapangan Terbimbing sebesar 20,8\%, sedangkan sisanya sebesar 79,2\% dijelaskan oleh Variable lain yang tidak diteliti.

Kata Kunci: Microteaching, Praktik Lapangan Terbimbing, Kesiapan menjadi Guru Profesional

\section{INTRODUCTION}

Education is an essential element in human life because education will improve the standard of human life in terms of social, economic, and environmental. The quality education in every community will be also created the quality resources that can give an impact on the progress of a community.

The condition of education in Indonesia is currently in an emergency, including violations of Human Rights, a poor ranking of Indonesian education, corruption cases against the education budget, and an education system that has not gone well (Komnas HAM RI, 2018). The Indonesian education system that has not run optimally can be caused by three things, namely a nonconducive school environment, an education curriculum that burdens students, and a low level of educators quality as the main factor. One way to overcome the problem of education in Indonesia that needs to be given more attention is to improve the quality of educators or teachers.

The teacher is one of the educational staff responsible for the implementation and success of the learning process. The government has made various efforts in supporting the improvement of the quality of teachers in the field of education, including by giving direction and upgrading to teaching staff to be more professional in empowering their students so that they can carry out their obligations properly (Hasmiana Hasan, 2015).

Quality education will not materialize without professional teachers. In Government Regulation, No. 74 of 2008 concerning Teachers, said that teachers must have academic qualifications, competencies, educator certificates, physically and mentally healthy, and the ability to realize national education goals. Teachers as educators are required to be professionals and must have existing competencies. The competencies that must be possessed by professional teachers are listed in the Republic of Indonesia's Minister of National Education Regulation No. 16 of 2007 concerning Standards for Teacher Qualifications and Competencies, including pedagogical competencies, personality competencies, social competencies, and professional competencies. With the fulfillment of these four competencies, a teacher will be able to improve his ability to educate so that he can anticipate various changes and developments in the times, and be able to design and implement teaching and learning activities that refer to excellent teaching and learning processes (Agus Suharno, 2008).

The reality in the field shows that not a few teachers do not have adequate competence. Not a few teachers are caught up in the misconception of teaching where teaching is merely an activity to convey material and knowledge without regard to the psychological conditions of their students, and not a few teachers take shortcuts by not making plans for implementing learning for various reasons. This has an impact on the inhibition of the development of students in teaching and learning activities (Suharsimi Arikunto, 2008).

Under Law No. 14 of 2005 concerning Teachers and Lecturers stated that the Educational Personnel Education Institution is a university that is given the task by the government to organize teacher procurement programs in early childhood education in 
formal education, primary education, and/or secondary education, and to organize and develop education and non-education sciences. In line with this, State University of Yogyakarta is a college that educates young educators who have prepared various scholarly study programs to bridge students in channeling their interests into a teacher. One of the educational study programs available at State University of Yogyakarta is the Accounting Education Study Program at the Faculty of Economics (FE) which is intended for students who have an interest in becoming an accounting teacher/lecturer. The Accounting Education Study Program is in charge of preparing prospective accounting teachers by educating and training them in becoming an educator in the future.

As a support for the existence of the Education Study Program as well as creating professional educators, State University of Yogyakarta has provided facilities and a real understanding of competencies to become professional teachers. The competence to become a professional teacher is summarized in the required compulsory subjects including Learning Strategy, Learning Media and Information Technology, Learning Assessment, Microteaching, and Guided Field Practice (PLT).

Microteaching is one of the essential subjects for education students who focus on providing direction related to strengthening student competencies as qualified teacher candidates so that in the next stage students will be prepared to carry out the guided field practice (PLT) well and maximally. The reality in the field shows that with the Microteaching method carried out by making students/peers as students and relatively short implementation time, the purpose of Microteaching as one of the subjects in forming quality teachers for students becomes less than the maximum results. Microteaching lacks understanding of the competencies that students must possess when implementing PLT, so it is assumed that the effect of the results of Microteaching learning on students in obtaining competence as professional teachers has not been fulfilled. This is reinforced by the results of a survey in the field that not a few students still find it challenging to prepare and carry out learning during the Microteaching course. When the implementation of the Guided Field Practice (PLT) took place, there were still students who found it difficult to manage classes or provide subject matter. The obstacles experienced by these students have an impact on practical learning situations that cannot be achieved or not even as planned in the learning program plan (RPP) they have made.

Difficulties faced by students during the implementation of Microteaching and Guided Field Practices (PLT) activities, one of which can be caused by lack of interest and Readiness to Become Professional Teacher. Based on the survey conducted by researchers to 63 students of the 2015 Accounting Force Education Faculty of State University of Yogyakarta, there were only 24 students $(38,10 \%)$ who were interested and had work plans as accounting teachers after graduating S1 Accounting while the remaining 39 students $(61,90 \%)$ were do not plan to work as accounting teachers but work as practitioners of accountants, entrepreneurs, and others. It proves that the readiness of students to become professional teachers is not optimal because most students have future goals and choose jobs that are not following with their fields.

\section{RESEARCH METHOD}

This research is a study using a quantitative approach. The subjects in this study are students of the Accounting Education Study Program, Faculty of Economics, State University of Yogyakarta Class of 2015 who are still active per semester 7 or December 2018. Other requirements that must be met by the study population are students who had passed Microteaching courses and participated in Guided Field Practices (PLT). The population in this study consisted of 2 classes 
totaling 63 students. Therefore, this study is a population research.

In this study, data collection techniques uses a Questionnaires with a Likert scale that be used to measure variables Microteaching Quality, Guided Field Practice and Readiness to Become Professional Teacher. Dependent variable is Readiness to Become Professional Teacher (Y) and Independent variables are Microteaching Quality (X1) and Guided Field Practice (X2). Data analysis method uses validity test, reliability test, descriptive statistical analysis, prerequisite test analysis, multiple regression analysis, and determine the coefficient of determination.

\section{RESULT AND DISCUSSION}

Descriptive analysis describes the mean, standard deviation, minimum value, and maximum value. Indicators used to measure the Microteaching Quality variable are Objectives of Microteaching, Benefits of Microteaching, and Implementation of Microteaching. The descriptive analysis results of the Microteaching Quality variable showed, from 63 students on 17 statement items that measured the Microteaching Quality have the highest score of 65 and the lowest scores of 46. The average score of the Microteaching Quality students in Accounting Education Study Program State University of Yogyakarta 2015 of 56,30 which is included in the medium category.

Indicators used to measure the Guided Field Practice (PLT) variable are Learning Preparation, Teaching Practice, Compile and Develop Learning Media, Compile and Develop Evaluation Tools, and Non-teaching Activities. The descriptive analysis results of the Guided Field Practice (PLT) variable showed, from 63 students on 16 statement items that measured the Guided Field Practice (PLT) have the highest score of 62 and the lowest scores of 44 . The average score of the Guided Field Practice (PLT) students in Accounting Education Study Program State University of Yogyakarta 2015 of 52,44 which is included in the medium category.
Indicators used to measure the Readiness to Become Professional Teacher variable are Pedagogical Competence, Personality Competence, Professional Competence, and Social Competence. The descriptive analysis results of the Readiness to Become Professional Teacher variable showed, from 63 students on 18 statement items that measured the Readiness to Become Professional Teacher have the highest score of 68 and the lowest scores of 49. The average score of the the Readiness to Become Professional Teacher students in Accounting Education Study Program State University of Yogyakarta 2015 of 58,75 which is included in the high and medium category.

Before testing hypotheses, the classic assumption test is carried out as a prerequisite for testing hypotheses including normality, linearity, multicollinearity, and heteroscedasticity. From the normality test, it is known that the Asymp Sig KolmogorovSmirnov value for the Microteaching Quality variable is 0,052, Guided Field Practice (PLT) variable is 0,200 and the Readiness to Become Professional Teacher variable is 0,200 . So it can be concluded that the data is normally distributed because of $>5 \%$.

The results of the linearity test show that there is a linear relationship between the independent variable and the dependent variable because of the sig value. $>0.05$. It is known that the sig value for the Microteaching Quality variable is 0,127 and the Guided Field Practice (PLT) variable is 0,668 . The multicollinearity test results obtained tolerance values of each variable is greater than 0,1 and VIF value $<10 \%$, so it can be concluded that there is no multicollinearity between variables in the regression model. The results of heteroscedasticity test using a Spearman Rank Test with the residual Readiness to Become Professional Teacher as the dependent variable. It can be known that the significance value for the Microteaching Quality variable of 0,887 and Guided Field Practice (PLT) of 0.605. Therefore, it can be concluded that the regression equation does 
not occur heteroscedasticity because the significance is greater than $5 \%$,

The coefficient of determination (R2) is used to find out how much the influence of variable X (Microteaching Quality, Guided Field Practice) on Y (Readiness to Become Professional Teacher) simultaneously. The result of determination coefficient in this study can be seen table 1 .

\section{Table 1. Determination Coefficient}

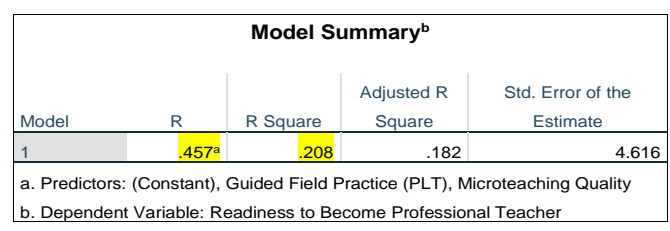

The value of $\mathrm{R}$ Square is equal to 0.208 or $20,8 \%$. This means $20,8 \%$ of the Readiness to Become Professional Teacher of the Accounting Education Students Economics Faculty State University of Yogyakarta Class of 2015 influenced by Microteaching Quality and Guided Field Practice (PLT). While the remaining $79,2 \%$ is influenced by other factors that not discussed in this study.

Multiple regression analysis is used to determine the effect of Microteaching Quality (X1), and Guided Field Practice (PLT) (X2) on the Readiness to Become Professional Teacher (Y), so it is necessary to know the regression equation. The summary of the results of hypotheses testing in this study can be seen in table 2 .

\section{Table 2. Result of Hypotheses Testing}

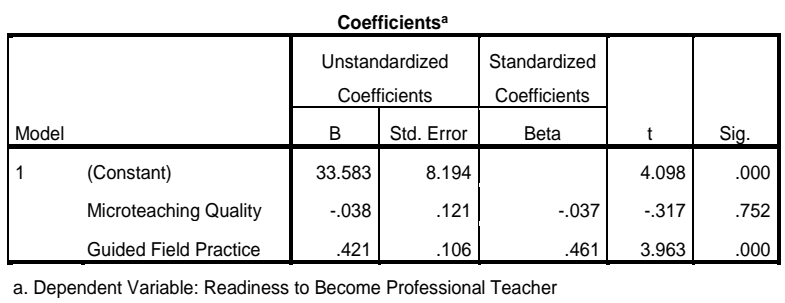

The Effect of Microteaching Quality on Readiness to Become Professional Teacher

Based on the results of partial calculations, the effect of Microteaching Quality on Readiness to Become Professional Teacher obtained a regression coefficient of 0.038 . In addition, it is known that $t_{\text {count }}$ is -
0.317 with a significance value of 0.752 . With the regression coefficient that has a negative value direction and a significance value of $>5 \%$, even though it uses $10 \%$ significance, it can be concluded that Readiness to Become Professional Teacher of the Accounting Education Student State University of Yogyakarta class of 2015 is not effected by Microteaching Quality.

The results of the initial survey indicated that the entire study population, namely the Accounting Education Student State University of Yogyakarta class of 2015, amounting to 63 students, has passed the Microteaching subject. The terms pass on Microteaching subject is rated at least B + score and these score become a requirement in following the Guided Field Practice (PLT) on the next semester. The details of the Microteaching subject score at the Accounting Education Student State University of Yogyakarta class of 2015 are as shown in table 3.

Table 3. Score Details of Micro Teaching Subject

\begin{tabular}{|c|c|c|c}
\hline No. & Value & Amount of Students & Percentage \\
\hline 1. & A & 55 & $87 \%$ \\
\hline 2. & A- & 5 & $8 \%$ \\
\hline 3. & B & 2 & $3 \%$ \\
\hline 4. & B+ & 1 & $2 \%$ \\
\hline & Total & $\mathbf{6 3}$ & $\mathbf{1 0 0 \%}$ \\
\hline
\end{tabular}

From the score details of the Microteaching subject described in table 3, it can be seen that all students have passed the Microteaching subject with $87 \%$ of them having very satisfying grades. The survey results on the score of Microteaching subject are contrary to the results of the first hypotheses research in this study. Although students have complete grades in the Microteaching subject, this does not have a significant effect on the Readiness of students to Become a Professional Teacher.

The results of this study are in line with the research conducted by Wi Indah (2014) which shows that there is no positive relationship between the Value of Micro Teaching to the Teaching Ability of Field Experience Practices (PPL). Based on the study results, it was concluded that not all students who have good microteaching score 
are also good at teaching. This is because any other factors that influence the students ability to teach both internally and externally, namely from personality, family, environment, and so on. The reason that $\mathrm{Wi}$ Indah (2014) research can supports this study is because the authors assumed that when students have the ability to teach, students will also have the Readiness to Become Professional Teachers. This is similar to what expressed by Dalyono (2009) and Slameto (2013) in the studies of the above theory, that readiness can be summed up as a willingness and sufficient ability both physically and mentally in doing something skillfully.

According to Kartono (1991) in Sausan's research (2017) states that the work readiness factor is by internal factors and external factors, one of which is interests and future goals. If someone already has an interest and future goals, he already has a view of his future and he will prepare himself to realize that goals.

Thus, the results of Microteaching learning does not have a significant effect on the students Readiness to Become Professional Teachers. It because there are only 24 students from 63 total populations who have interests and work plans to become a teacher. Even from 55 students with very satisfying score on microteaching, only 22 students of them had work plans to become teachers, besides of them are want to become accounting practitioners, entrepreneurs, and so on. This is because there are other variables not examined in this study that effect the Readiness to Become Professional Teachers, namely interests and future goals, so that students' interests and future goals besides being a teacher can change students' perceptions of their Readiness to Become Professional Teacher.

\section{The Influence of Guided Field Practices (PLT) on Readiness to Become Professional Teacher}

Based on the results of partial calculations, the effect of Guided Field Practice (PLT) on Readiness to Become
Professional Teacher obtained a regression coefficient of 0.421 . In addition, the calculation results show a $t_{\text {count }}$ value of 0.461 with a significance value of 0,000 . With the results of the study showing that the regression coefficient of the Guided Field Practice (PLT) has a positive value direction and significance value $<0.05$, it can be concluded that the Guided Field Practice (PLT) has an effect on Readiness to Become Professional Teachers of the Accounting Education Student State University of Yogyakarta class of 2015. The better of the Guided Field Practice (PLT) quality, the better it will be also the readiness of students to become a Professional Teacher.

The results of this study are supported by the opinion of the drafting team of the UNY PLT guidebook (2017) which revealed that the PLT program is a program that aims to develop teaching competencies in educational students as prospective teachers/educators or education personnel. While Slameto (2010) states that the experience gained by humans has a positive influence on readiness. In this study, the readiness of that statement is the Readiness to Become Professional Teacher. The most concrete experience gained by educational students is the Guided Field Practice (PLT). Therefore, due to the lack of practical experience in the form of a Guided Field Practices (PLT), the students will be ready to implement learning activities in the classroom as a professional teacher.

The results of this study are also in line with the research conducted by Yurike Praptiana (2017) with the results of research that showed a positive effect of Field Experience Program (PPL) on student Readiness to Become Professional Teachers. This is evidenced by the highest frequency with 27 students $(37.5 \%)$ able to carry out pre-learning well. In addition, Maya's research (2016) also supports the results of this study by showing that the Field Experience Program (PPL) has an effect on students Readiness to Become a Teachers 
with the results is $t_{\text {count }}>t_{\text {table }}(8,392>$ $1,664)$ and significance values $(0,000<0,05)$.

\section{CONCLUSIONS AND SUGGESTIONS Conclusions}

Based on the data obtained from the results of the analysis conducted, conclusions can be taken that Readiness to Become Professional Teacher on Accounting Education Students at the State University of Yogyakarta class of 2015 is not effected by the Quality of Microteaching that students have taken during college. But, Guided Field Practices (PLT) which students take after passing the Microteaching have an influence on the Readiness to Become Professional Teachers on on Accounting Education Students at the State University of Yogyakarta force 2015.

\section{Suggestion}

Based on the results of research and discussion that have been described, the researcher can provide suggestions as follows:

a. Students should study more about the kinds of literature that relating to research, education, and accounting material, so that students will have the knowledge and insights relating to a wider world of accounting education.

b. Microteaching learning must be carried out more optimally and it is necessary to make improvements so that students can do the Guided Field Practice maximally untill they have the Readiness to Become Professional Teacher.

c. The effective contributions given by the two independent variables are $20.8 \%$. This shows that Readiness to Become Professional Teacher is not only effected by two variables only, namely the Microteaching Quality or Guided Field Practice (PLT). There are still $79.2 \%$ of other variables that affect the Readiness to Become Professional Teachers which are not examined in this study. Thus, expected in the next research could examine other factors that can effect the Readiness to Become Professional Teachers.

\section{REFERENCES}

Arikunto, Suharsimi. (2013). Prosedur Penelitian: Suatu Pendekatan Praktik. Jakarta: Rineka Cipta

Dalyono. (2009). Psikologi Pendidikan. Jakarta: PT. Rineka Cipta

Hasan, Hasmiana. (2015). Kendala yang Dihadapi Guru dalam Proses Belajar Mengajar Matematika di SD Negeri Gani Kabupaten Aceh Besar. Jurnal Pesona Dasar, Vol. 1, h.40-41

Kemendiknas. (2005). Undang-undang Nomor 14 dan 15 Tahun 2005 tentang Gru dan Dosen

$\begin{array}{llrr}\text { (2007). Peraturan } & \text { Menteri } \\ \text { Pendidikan Nasional } & \text { Republik } \\ \text { Indonesia Nomor } & 16 \text { Tahun } 2007 \\ \text { tentang Standar } & \text { Kualifikasi dan } \\ \text { Kompetensi Guru } & & \end{array}$
. (2008). Peraturan Pemerintah Nomor 74 Tahun 2008 tentang Guru

Komnas HAM. (2018). Siaran Pers Komisi Nasional Hak Asasi Manusia Republik Indonesia

Maya. (2016). Pengaruh Mata Kuliah Microteaching dan Program Pengalaman Lapangan terhadap Kesiapan menjadi Guru Mahasiswa Pendidikan Tata Niaga 2012 Universitas Negeri Medan. Skripsi: Uniersitas Negeri Medan

Nafisah, S.A. (2017). Hubungan antara Orientasi Masa Dpean dengan Kesiapan Kerja Siswa SMK. Skripsi: Universitas Muhammadiyah Surakarta

Najjah, W.I.S. (2014). Pengaruh Nilai Micro Teaching terhadap Kemampuan 
Nabila Sofiarani \& Arief Zuliyanto Susilo

$38-45$

Mengajar Praktek Pengalaman

Lapangan (PPL) Mahasiswa S1

Program Studi Tadris Biologi Angkatan 2010 Fakultas Ilmu Tarbiyah dan Keguruan IAIN Walisongo Semarang. Skripsi: IAIN Walisongo Semarang

Praptina, Yurike. (2017). Pengaruh Praktik Pegalaman Lapangan (PPL), Minat, dan Prestasi Belajar terhadap Kesiapan menjadi Guru Profesional Mahasiswa Fakultas Ekonomi Angkatan 2013 Universitas Negeri Yogyakarta. Skripsi: Universitas Negeri Yogyakarta

Slameto. (2013). Belajar dan Faktor-faktor yang Mempengaruhinya. Jakarta: PT. Rineka Cipta

Suharno, Agus. (2008). Pentingnya Profesionalisme Guru dalam Meningkatkan Kualitas Pendidikan. Artikel Jurnal Majalah Ilmiah Lontar. Vol.22, no..2 